\title{
MAJAS \\ (MAJAS PERBANDINGAN, MAJAS PERTENTANGAN, MAJAS PERULANGAN, MAJAS PERTAUTAN) )
}

\author{
Surianti Nafinuddin \\ suriantiunismuh123@gmail.com
}

\begin{abstract}
Abstrak
Majas atau gaya bahasa yaitu pemanfaatan kekayaan bahasa, pemakaian ragam tertentu untuk memperoleh efekefek tertentu yang membuat sebuah karya sastra semakin hidup, keseluruhan ciri bahasa sekelompok penulis sastra dan cara khas dalam menyampaikan pikiran dan perasaan, baik secara lisan maupun tertulis. Majas umumnya digunakan dalam penulisan karya sastra, termasuk di dalamnya puisi dan prosa. Majas sendiri adalah sebuah seni tulis atau lisan persuasif yang pertama kali dikembangkan di era Yunani kuno. Jika kita membubuhkan seni ini ke dalam tulisan kita, maka kita bisa bermain dengan kata-kata. Tujuannya sederhana, memperkaya pemilihan kata dan bahasa dalam karya. Artinya sendiri bisa berbeda tergantung pada konteks penggunaannya. Secara umum, majas dibagi ke dalam empat kategori, yakni majas perbandingan, majas pertentangan, majas perulangan dan majas pertautan.

Keyword: majas, gaya bahasa, linguistik, sastra
\end{abstract}

\begin{abstract}
Majas or style of language that is the use of a wealth of language, the use of certain variations to obtain certain effects that make a literary work more alive, the overall characteristics of a group of literary writers and a unique way of conveying thoughts and feelings, both verbally and in writing. Majas is generally used in writing literary works, including poetry and prose. Majas itself is a persuasive written or oral art that was first developed in the era of ancient Greece. If we put this art into our writing, then we can play with words. The goal is simple, enriching the choice of words and languages in the work. The meaning itself can be different depending on the context of its use. In general, majas is divided into four categories, namely comparative majeure, contravention majeure, repetition majeure and linkage majeure.
\end{abstract}

Keyword: style linguist, style, linguistics, literature, literature 


\title{
Majas atau Gaya Bahasa
}

\author{
Pengertian Majas
}

Majas merupakan salah satu unsur yang menarik dalam sebuah bacaan. Pengarang memiliki gaya yang berbeda-beda dalam menuangkan setiap ide tulisannya. Setiap tulisan yang dihasilkan nantinya mempunyai gaya yang dipengaruhi oleh penulisnya, sehingga dapat dikatakan, watak seorang penulis sangat mempengaruhi sebuah karya yang dihasilkannya. Hal ini relevan dengan pendapat Keraf yang mengatakan: Majas atau Gaya bahasa dapat dilihat dari dua sudut pandang yang berbeda, yakni dari segi non bahasa dan dari segi bahasa. Dari segi nonbahasa, gaya dapat dikategorikan berdasarkan pengarang, waktu, media, permasalahan, tempat, tujuan, dan sasaran, sementara itu dari segi bahasa gaya bahasa dikategorikan berdasarkan pilihan kata, pilihan nada, struktur kalimat, dan penyampaian kalimat (2009:115).

Menurut Keraf (2006: 113) pengertiaan gaya atau khususnya gaya bahasa dikenal dalam retorika dengan istilah style. Kata style itu sendiri berasal dari kata Latin stilus yang berarti semacam alat untuk menulis pada lempengan lilin. Majas atau Gaya bahasa adalah cara pengungkapan pikiran melalui bahasa secara khas yang memperlihatkan jiwa kepribadian penulis atau pemakai bahasa. Sama halnya dengan Keraf, dalam memberikan pengertian terhadap gaya bahasa. Dalam kaitannya dengan gaya bahasa terdapat istilah-istilah lain yang mungkin muncul, di antaranya: seni bahasa, estetika bahasa, kualitas bahasa, ragam bahasa, gejala bahasa, dan rasa bahasa. Dua istilah pertama memiliki penertian yang hampir sama yaitu bahasa dalam kaitannya dengan ciri-ciri keindahan sehingga identik dengan gaya bahasa itu sendiri. Kualitas bahasa berkaitan dengan nilai penggunaan bahasa secara umum, termasuk ilmu pengetahuan. Ragam bahasa adalah genre (jenis sastra). Gejala bahasa dalam pengertian sempit menyangkut perubahan (penghilangan, pertukaran) dalam sebuah kata, sedangkan dalam pengertian luas menyangkut berbagai bentuk perubahan bahasa baik lisan maupun tulis, majas termasuk dalam gejala bahasa yang paling khas.

Rasa bahasa adalah perasaan yang timbul sesudah mendengarkan, menggunakan suatu ragam bahasa tertentu. (Ratna, 2009: 4). Majas memiliki tujuan utama yaitu memunculkan aspek keindahan. Dalam karya sastra gaya bahasa memegang peranan penting, karena merupakan unsur pokok yang digunakan untuk mencapai berbagai bentuk keindahan. Dalam hubungannya dengan gaya bahasa, karya sastra sebagai salah satu genre hasil peradaban manusia dan merupakan hasil aktivitas pengarang, maka menggunakan bahasa sebagai media utama. Jadi gaya bahasa yang dimaksudkan pada suatu karya sastra berkaitan erat dengan tujuan dan pribadi pengarang.

Aminuddin (1995: 4) memberi penjelasan bahwa gaya bahasa atau style merupakan teknik serta bentuk gaya bahasa seseorang dalam memaparkan gagasan sesuai dengan ide dan norma yang digunakan sebagai mana ciri pribadi pemakainya. Pengertian gaya bahasa tersebut dikemukakan pada wawasan retorika klasik. Jadi, gaya bahasa pada masa retorika klasik dipandang sebagai sejenis ornamen atau perhiasan lahir atau yang di dalam tradisi Jawa disebut basa rinengga atau pemakaian bahasa yang dihias sehingga kelihatan indah. Akan tetapi, pada komunikasi modern, style bukan hanya dihubungkan 
dengan penggunaan bahasa yang indah, akan tetapi juga memberikan kesadaran bahwa hal yang menarik dari penggunaan bahasa dalam peristiwa komunikasi adalah aspek bentuk yang diembannya.

Pengertian gaya menurut (Enkvist dalam Aminuddin, 1995: 6) yaitu (a) gaya sebagai bungkus yang membungkus inti pemikiran atau pernyataan yang telah ada sebelumnya, (b) gaya sebagai pilihan antara berbagai pernyataan yang mungkin, (c) gaya sebagai kumpulan ciri pribadi, (d) gaya sebagai bentuk penyimpangan norma atau kaidah, (e) gaya sebagai kumpulan ciri kolektif, dan ( $f$ ) gaya sebagai bentuk hubungan antara satuan bahasa yang dinyatakan teks yang terlebih dahulu dari pada sebuah ayat atau kalimat.

Kridalaksana (2001: 63) memberikan pengertian gaya bahasa atau style adalah (1) pemanfaatan atas kekayaan bahasa oleh seseorang dalam bertutur atau menulis; (2) pemakaian ragam tertentu untuk memperoleh efek-efek tertentu; (3) keseluruhan ciri-ciri bahasa sekelompok penulis sastra. Menurut Pradopo (1997: 137) gaya bahasa adalah cara penggunaan bahasa yang khusus untuk mendapatkan efek-efek tertentu dalam suatu karya sastra, sedangkan menurut Sudjiman (1993: 50) gaya bahasa atau majas adalah peristiwa pemakaian kata yang melewati batas-batas maknanya yang lazim atau menyimpang dari arti harfiahnya. Style (gaya bahasa), adalah cara pengucapan bahasa dalam prosa, atau bagaimana seseorang mengungkapkan sesuatu yang akan dikemukakan (Abrams dalam Nurgiantoro, 1995: 276).

Gaya bahasa berdasarkan struktur kalimat dihasilkan dari pendayagunaan struktur kalimat. Gaya bahasa yang dihasilkan bersifat nyata berbeda dengan gaya bahasa berdasarkan penyampaian makna yang sifatnya abstrak atau konotasi. Keraf berpendapat: Struktur kalimat adalah bagaimana sebuah kalimat menjadi tempat sebuah unsur kalimat yang dipentingkan dalam kalimat tersebut. Misalnya antitesis, repetisi, klimaks, antiklimaks, dan paralelisme. Sementara itu, gaya bahasa berdasarkan penyampaian makna disebut figure of speech yaitu penyimpangan bahasa secara emotif dari bahasa biasa dalam ejaan, pembentukan kata, konstruksi, untuk memperoleh kejelasan, penekanan, hiasan, humor, dan efek-efek tertentu (2009: 129).

Style ditandai oleh ciri-ciri formal kebahasaan seperti pemilihan kata, struktur kalimat, bentuk-bentuk bahasa figuratif, penggunaan kohesi dan lain-lain. Gaya bahasa dapat ditinjau dari bermacam-macam sudut pandang. Pandangan terhadap gaya bahasa dapat dibedakan dari jenisnya dibagi menjadi dua segi yakni segi non bahasa dan segi bahasa. Guna melihat gaya secara luas, maka pembagian berdasarkan masalah non bahasa tetap diperlukan, namun gaya bahasa dilihat dari aspek kebahasaan lebih diperlukan.

\section{Bentuk-bentuk Majas}

Menurut Depdiknas (2005) gaya bahasa atau majas adalah pemanfaatan kekayaan bahasa, pemakaian ragam tertentu untuk memperoleh efek-efek tertentu, keseluruhan ciri bahasa sekelompok penulis sastra dan cara khas dalam menyatakan pikiran dan perasaan baik secara lisan maupun tertulis. Meskipun ada banyak macam gaya bahasa atau majas, namun secara sederhana gaya bahasa terdiri dari empat macam, yaitu majas perbandingan, majas penegasan, majas pertentangan, dan majas sindiran. 
1. Majas perbandingan, meliputi: alegori, alusio, simile, metafora, sinestesia, antropomorfemis, antonomesia, aptronim, metonemia, hipokorisme, litotes, hiperbola, personifikasi, pars prototo, totum proparte, eufemisme, depersonifikasi, disfemisme, fabel, parabel, perifrase, eponim, dan simbolik.

2. Majas penegasan, meliputi: apofasis, pleonasme, repetisi, pararima, aliterasi, paralelisme, tautologi, sigmatisme, antanaklasis, klimaks, antiklimaks, inversi, retoris, elipsis, koreksio, sindeton, interupsi, eksklamasio, enumerasio, preterito, alonim, kolokasi, silepsis, dan zeugma.

3. Majas pertentangan, meliputi: paradoks, antitesis, oksimoron, kontradiksi interminus, dan anakronisme.

4. Majas sindiran, meliputi: ironi, sarkasme, sinisme, satire, inuendo, dan lain-lain (Depdiknas (2007).

Senada dengan pendapat di atas, ahli lain membagi jenis-jenis gaya bahasa menjadi empat kelompok, yaitu sebagai berikut.

1. Gaya bahasa berdasarkan pilihan kata dibedakan menjadi gaya bahasa resmi, gaya bahasa tak resmi, dan gaya bahasa percakapan.

2. Gaya bahasa berdasarkan nada terdiri dari gaya sederhana, gaya mulia dan bertenaga, dan gaya menengah.

3. Gaya bahasa berdasarkan struktur kalimat terdiri dari klimaks, antiklimaks, paralelisme, antitesis, dan repetisi.

4. Gaya bahasa berdasarkan langsung tidaknya makna terdiri dari gaya bahasa retoris meliputi aliterasi, asonansi, anastrof, apofasis atau preterisio, apostrof, asidenton, polisidenton, kiasmus, elipsis, eufemismus, litotes, hysteron proteron, pleonasme dan tautologi, perifrasis, prolepsis, erotesis, silepsis dan zeugma, koreksio, hiperbol, paradoks, oksimoron; dan gaya bahasa kiasan meliputi metafora, simile, alegori, personifikasi, alusi, eponimi, epitet, sinekdoke, metonimia, antonomasia, hipalase, ironi, sinisme, dan sarkasme, satire, inuendo, antifrasis dan pun atau paronomasia (Keraf, 2000: 115-145).

Gaya bahasa berdasarkan penyampaian makna terdiri dari dua kelompok yakni gaya bahasa retoris dan gaya bahasa kiasan. Gaya bahasa retoris merupakan gaya bahasa yang maknanya diartikan secara harfiah sesuai dengan makna lahirnya. Bahasa yang digunakan mengandung kelangsungan makna. Misalnya asindeton, polisindeton, litotes, hiperbola, anastrof dan sebagainya. Sementara itu gaya bahasa kiasan merupakan gaya bahasa yang maknanya tidak dapat ditafsirkan sesuai dengan kata-kata yang membentuknya. Gaya bahasa kiasan diperoleh dengan cara membandingkan atau mempersamakan sesuatu hal dengan hal lain. Bahasa kiasan adalah teknik pengungkapan bahasa yang maknanya tidak menunjukkan pada makna harfiah kata-kata yang mendukungnya tetapi pada makna yang tersirat. Ketidaklangsungan makna inilah yang merupakan salah satu siasat penulis untuk menarik perhatian pembaca (Nurgiyantoro, 2005). 


\section{a. Majas Perulangan}

Majas perulangan yaitu majas yang cara cara melukiskan suatu keadaan dengan cara mengulang-ulang kata, frase, suatu maksud. Yang termasuk ke dalam majas ini antara lain majas anaphora, tautologi, repetisi, epifora, dan lain-lain.

1) Repetisi

Repetisi merupakan majas perulangan kata, frase, dan klausa yang sama dalam suatu kalimat. Majas repetisi ialah majas perulangan yang cara melukiskan suatu hal dengan mengulang-ulang kelompok kata atau frasa yang sama (Ducrot dan Todorov, 1981 : 279).

\section{Contoh:}

Seumpama eidelwis akulah cinta abadi yang tidak akan pernah layu.

Seumpama merpati akulah kesetiaan yang tidak pernah ingkar janji.

Seumpama embun akulah kesejukan yang membasuh hati yang lara.

Seumpama samudra akulah kesabaran yang menampung keluh kesah segala muara.

2) Kiasmus

Kiasmus ialah gaya bahasa yang berisikan perulangan dan sekaligus merupakan inversi atau pembalikan susunan antara dua kata dalam satu kalimat. Majas kiasmus merupakan bentuk majas perulangan yang isinya mengulang atau repetisi sekaligus merupakan inversi hubungan antara dua kata dalam satu kalimat (Ducrot dan Todorov, $1981: 277$ )..

Contoh:

Yang kaya merasa dirinya miskin, sedang yang miskin mengaku dirinya kaya. Sudah biasa dalam kehidupan sehari-hari, orang pandai ingin disebut bodoh, namun banyak orang bodoh mengaku pandai.

la menyalahkan yang benar dan membenarkan yang salah.

\section{3) Epizeukis}

Epizeukis ialah gaya bahasa perulangan yang bersifat langsung. Maksudnya kata yang dipentingkan diulang beberapa kali berturut-turut. Hal ini dilakukan dengan maksud untuk menegaskan.

Contoh :

Kita harus bekerja, bekerja, dan terus bekerja untuk mengejar semua ketertinggalan kita. Ingat, kita harus bertobat, bertobat, sekali lagi bertobat!

4) Tautotes

Tautotes ialah gaya bahasa perulangan yang berupa pengulangan sebuah kata berkali-kali dalam sebuah konstruksi.

Contoh : 
Kau menunding aku, aku menunding kau, kau dan aku menjadi seteru.

Aku adalah kau, kau adalah aku, kau dan aku sama saja.

5) Anafora

Anafora ialah gaya bahasa repetisi yang merupakan perulangan kata pertama pada setiap baris atau kalimat. Majas anafora merupakan bentuk majas perulangan yang menempatkan kata atau frasa yang sama di depan suatu puisi (Suprapto, 1991 : 11).

Contoh :

Apatah tak bersalin rupa, apatah boga sepanjang masa.

Kucari kau dalam toko-toko.

Kucari kau karena cemas karena sayang.

Kucari kau karena sayang karena bimbang.

Kucari kau karena kau mesti disayang.

6) Epistrofa (efifora)

Epistrofa ialah gaya bahasa repetisi yang berupa perulangan kata atau frasa pada akhir baris atau kalimat berurutan. Majas epifora merupakan majas repetisi atau perulangan yang cara melukiskannya dengan menempatkan kata atau kelompok kata yang sama di belakang baris dalam bentuk puisi secara berulang (Suprapto, $1991: 27$ ).

Contoh :

Kalau kau izinkan, aku akan datang.

Jika sempat, aku akan datang.

Jika kau terima, aku akan datang.

Jika tak hujan, aku akan datang.

7) Simploke

Simploke ialah gaya bahasa repetisi yang berupa perulangan awal dan akhir beberapa baris (kalimat secara berturut-turut).

Contoh :

Kau bilang aku ini egois, aku bilang terserah aku.

Kau bilang aku ini judes, aku bilang terserah aku.

Ada selusin gelas ditumpuk ke atas. Tak pecah.

Ada selusin piring ditumpuk ke atas. Tak pecah.

Ada selusin barang lain ditumpuk ke atas. Tak pecah.

8) Mesodiplosis

Mesodiplosis ialah gaya bahasa repetisi yang berupa pengulangan kata atau frase di tengah-tengah baris atau kalimat secara berturut-turut.

Contoh :

Para pembesar jangan mencuri bensin.

Para gadis jangan mencuri perawannya sendiri. 
Para pendidik harus meningkatkan kecerdasan bangsa.

Para dokter harus meningkatkan kesehatan masyarakat.

9) Epanalepsis

Epanalepsis ialah gaya bahasa repetisi yang berupa perulangan kata pertama pada akhir baris, klausa, atau kalimat mengulang kata pertama.

Contoh :

Kita gunakan pikiran dan perasaan kita.

Saya akan berusaha meraih cita-cita saya.

10) Anadiplosis

Anadiplosis ialah gaya bahasa repetisi yang kata atau frase terakhir dari suatu kalimat atau klausa menjadi kata atau frase pertama pada klausa atau kalimat berikutnya.

Contoh:

Dalam baju ada aku, Dalam aku ada hati.

Dalam hati : ah tak apa jua yang ada.

Dalam raga ada darah

Dalam darah ada tenaga

Dalam tenaga ada daya

Dalam daya ada segalanya

11) Pararima

Majas pararima merupakan pengulangan konsonan awal dan akhir dalam kata atau bagian kata yang berlainan. Pararima merupakan gaya bahasa yang pada mulanya menegaskan sesuatu yang dianggap kurang tepat kemudian diperbaiki.

Contoh:

Sepertinya saya pernah menyampaikan hal ini dua hari yang lalu. Ah bukan, kemarin.

Tujuan kami menghadap Pak Lurah, ingin mengadakan acara parade bedug, maksudnya meminta izin untuk mengadakan parade bedug.

12) Aliterasi

Sejenis gaya bahasa yang berwujud perulangan konsonan pada suatu kata atau beberapa kata, biasanya terjadi pada puisi. Aliterasi merupakan majas perulangan yang memanfaatkan purwakanti atau katakata yang suku kata awalnya memiliki persamaan bunyi (Suprapto, 1991: : 6).

Contoh:

Mengalir, mengambus, mendesak, mengepung.

Memenuhi sukma, menawan tubuh.

Serasa manis semilir angin. 
Selagu merdu, dersik bayu.

Kau keraskan kalbunya.

Bagai batu membesi benar.

Timbul telangkai bertongkat urat.

Ditunjang pengacara petah pasih.

13) Asonansi

Asonansi ialah sejenis gaya bahasa perulangan yang berupa perulangan vokal, pada suatu kata atau beberapa kata. Biasanya dipergunakan dalam puisi untuk mendapatkan efek penekanan.

Contoh:

Segala ada menekan dada.

Mati api di dalam hati.

Harum sekuntum bunga rahasia.

Dengan hitam kelam.

b. Majas Perbandingan

Majas perbandingan adalah majas yang cara melukiskan keadaan apapun dengan menggunakan perbandingan antara satu hal dengan hal lain. Yang termasuk majas ini misalnya majas asosiasi, metafora, personifikasi, alegori, pleonasme, dan lain-lain.

1) Simile

Perumpamaan ialah padanan kata atau simile yang berarti seperti. Secara eksplisit jenis gaya bahasa ini ditandai oleh pemakaian kata: seperti, sebagai, ibarat, umpama, bak, laksana, serupa. Istilah simile berasal dari bahasa Latin simile yang bermakna seperti. Majas simile merupakan majas yang menggambarkan suatu keadaan dengan membanding-bandingkan suatu hal dengan hal lainnya yang pada hakikatnya berbeda namun disengaja untuk dipersamakan (Ducrot dan Todorov, 1981 : 279). Halhal tersebut dibandingkan secara eksplisit dengan penggunaan kata-kata seperi, bagaikan, laksana, umpama, dan lain-lain.

Simile merupakan pengungkapan dengan perbandingan eksplisit yang dinyatakan dengan kata depan dan pengubung, seperti layaknya, bagaikan, dan lain-lain. Simile adalah bahasa kiasan berupa pernyataan satu hal dengan hal lain dengan menggunakan kata-kata pembanding. Secara eksplisit jenis gaya bahasa ini ditandai oleh pemakaian kata: seperti, sebagai, ibarat, umpama, bak, laksana, serupa.

Contoh:

$\star \quad$ Seperti air di daun talas.

* Wajahnya bagaikan bulan kesiangan.

$\star$ Umpama kucing dengan tikus.

$\star \quad$ Laksana air dengan minyak. 
$\star$ Nyalakanlah semangat serupa dian nan tak kunjung padam.

$\star$ Bersabarlah ibarat samudra yang mampu menampung keluh kesah segala muara.

\section{2) Metafora}

Metafora berasal dari bahasa Yunani metaphora yang artinya memindahkan. Istilah metaphora diturunkan dari kata meta yang artinya di atas dan pherein yang artinya membawa (Tarigan, 1993 : 141). Suatu majas yang sering lali menimbulkan penambahan kekuatan dalam suatu kalimat. Majas metafora membatu orang yang berbicara atau menulis untuk menggambarkan hal-hal dengan jelas, dengan cara membanding-bandingkan suatu hal dengan hal lain yang emiliki ciri-ciri dan sifat yang sama.

Perbedaan metafora dengan simile yaitu, majas metafora bersifat implisit sedangkan majas simile bersifat eksplisit. Dibandingkan dengan majas lainnya, majas metafora merupakan majas yang paling singkat, padat, dan rapi. Poerwadarminta menjelaskan, metafora yaitu majas dengan pemakaian katakata yang memiliki arti lain, tetapi merupakan lukisan yang didasarkan persamaan atau perbandingan (1976 : 648)

\section{Contoh :}

$\star$ Pustaka itu gudangnya ilmu, dan membaca adalah kuncinya.

$\star$ Kesabaran adalah bumi.

$\star$ Kesadaran adalah matahari.

$\star$ Keberanian menjelma kata-kata.

* Dan perjuangan adalah pelaksana kata-kata (sebuah bait yang diambil dari puisi Rendra).

$\star$ Dewi malam telah keluar dari peraduannya (dewi malam = bulan).

\section{3) Personifikasi}

Personifikasi ialah gaya bahasa yang melekatkan sifat-sifat insani pada barang atau benda yang tidak bernyawa ataupun pada ide yang abstrak. Personifikasi merupakan pengungkapan dengan menggunakan perilaku manusia yang diberikan kepada sesuatu yang bukan manusia. Personifikasi adalah majas yang menerapakan sifat-sifat manusia terhadap benda mati. Personifikasi atau penginsanan adalah gaya bahasa yang mempersamakan benda-benda dengan manusia, punya sifat, kemampuan, pemikiran, perasaan, seperti yang dimiliki dan dialami oleh manusia.

Contoh:

$\star$ Angin bercakap-cakap bersama daun-daun, bunga-bunga, kabut dan titik embun.

$\star$ Indonesia menangis, duka nestapa Aceh memeluk dengan erat sanubari bangsaku.

\section{4) Depersonifikasi}

Depersonifikasi ialah gaya bahasa yang melekatkan sifat-sifat suatu benda tak bernyawa pada manusia atau insan. Biasanya memanfaatkan kata-kata: kalau, sekiranya, jikalau, misalkan, bila, seandainya, 
seumpama. Depersonifikasi: Pengungkapan dengan tidak menjadikan benda-benda mati atau tidak bernyawa. Depersonifikasi adalah majas yang berupa pembandingan manusia dengan bukan manusia atau dengan benda. Majas ini mirip dengan majas metafora.

Contoh:

Kalau engkau jadi bunga, aku jadi tangkainya.

5) Alegori

Alegori sering mengandung sifat-sifat moral spiritual. Biasanya alegori tersebut membangun cerita yang rumit dengan maksut yang terselubung. Cerita fabel dan parabel merupakan alegori-alegori yang pendek. Alegori yaitu gaya basa yang memperlihatkan perbandingan yang utuh, yang membentuk kemanunggalan kang paripurna, merupakan rangkaian cerita yang dipergunakan sebagai perlambang untuk mendidik atau menerangkan suatu hal (Suprapto, $1991: 10$ ).

Alegori ialah gaya bahasa yang menggunakan lambang-lambang yang termasuk dalam alegon antara lain: fabel dan parabel. Alegori ialah gaya bahasa yang menyatakan dengan cara lain, melalui kiasan atau penggambaran. Alegori adalah kata kiasan berbentuk lukisan/cerita kiasan, merupakan metafora yang dikembangkan.

Contoh:

Menuju ke Laut

(Sutan Takdir Alisjahbana)

Kami telah meninggalkan engkau, Tasik yang tenang tiada beriak, diteduhi gunung yang rimbun, dari angin dan topan.

Sebab sekali kami terbangun, dari mimpi yang nikmat.

Ombak riak berkejar-kejaran di gelanggang biru di tepi langit. Pasir rata berulang di kecup, tebing curam ditentang diserang, dalam bergurau bersama angin, dalam berlomba bersama mega. Sejak itu jiwa gelisah Selalu berjuang tiada reda. Ketenangan lama serasa beku, gunung pelindung rasa pengalang. Berontak hati hendak bebas, menyerang segala apa mengadang. Gemuruh berderau kami jatuh, terhempas berderai mutiara bercahaya.

Gegap gempita suara mengerang, Dahsyat bahna suara menang. 
Keluh dan gelak silih berganti, pekik dan tempik sambut menyambut.

Tetapi betapa sukanya jalan, bedana terhembas, kepala tertumbuk,. hati hancur, pikiran kusut, namun kembali tiada ingin. namun kembali diada angin,. ketenangan lama tiada diratap. Kami telah meninggalkan engkau, Tasik yang tenang tiada beriak, diteduhi gunung yang rimbun, dari angin dan topan.. Sebab sekali kami terbangun, dari mimpi yang nikmat.

6) Alusio

Alusio merupakan pemakaian ungkapan yang tidak diselesaikan karena sudah dikenal. Alusio adalah gaya bahasa yang menampilkan adanya persamaan dari sesuatu yang dilukiskan yang sebagai referen sudah dikenal pembaca.

Contoh:

Bandung dikenal sebagai Paris Jawa.

7) Antitesis

Secara kalamiah antitesis diturunkan dari kata 'antithesis' yang artinya 'musuh yang cocok' atau pertentangan sang yang benar-benar (Poerwadarminta, 1976 : 52). Majas antitesis tersebut sejenis majas yang sengaja mengadakan komparasi (perbandingan) antara dua antonim (yaitu dua kata yang memiliki ciri semantik yang sebaliknya). Antitesis ialah gaya bahasa yang mengandung gagasan-gagasan yang bertentangan.

Contoh:

Dia gembira atas kegagalanku dalam ujian.

8) Pleonasme

Pleonasme adalah penggunaan kata yang mubazir yang sebesarnya tidak perlu. Pleonasme merupakan majas yang dipergunakan dengan cara menambahkan keterangan pada pernyataan yang sudah jelas atau menambahkan keterangan yang sebenarnya tidak diperlukan.

Contoh:

Dia turun ke bawah $\rightarrow$ Dia turun

9) Tautologi

Tautologi adalah gaya bahasa yang menggunakan kata atau frase yang searti dengan kata yang telah disebutkan terdahulu. Tautologi merupakan pengulangan kata dengan menggunakan sinonimnya. 
Tautologi adalah sarana retorika yang menyatakan sesuatu secara berulang dengan kata-kata yang maknanya sama supaya diperoleh pengertian yang lebih mendalam. Tautologi merupakan suatu majas perulangan yang cara melukiskanya dengan mengulang-ulang kata yang ada dalam kalimat (Suprapto, $1991: 85)$.

Contoh :

Tak ada badai tak ada topan, tiba-tiba saja ia marah.

10) Perifrasis

Perifrasis ialah gaya bahasa yang dalam pernyataannya sengaja menggunakan frase yang sebenarnya dapat diganti dengan sebuah kata saja. Perifrase merupakan ungkapan yang panjang sebagai pengganti ungkapan yang lebih pendek. Parifrasis adalah majas yang berfungsi menggantikan serangkaian kata yang mempunyai arti sama.

Contoh:

$\star$ Nissa telah menyelesaikan sekolah dasarnya tahun 2008 (lulus).

$\star$ Kelima orang itu segera meninggalkan kampung kita (diusir).

$\star$ la telah dipanggil Sang Maha Pemilik Hidup (meninggal).

11) Antisipasi (prolepsis)

Antisipasi ialah gaya bahasa yang dalam pernyataannya menggunakan frase pendahuluan yang isinya sebenarnya masih akan dikerjakan atau akan terjadi. Prolepsis adalah majas yang menggunakan kalimat pendahuluan tetapi makna sebenarnya akan diketahui belakangan.

Contoh:

Aku melonjak kegirangan karena aku mendapatkan piala kemenangan.

12) Koreksio (epanortosis)

Koreksio ialah gaya bahasa yang dalam pernyataannya mula-mula ingin menegaskan sesuatu. Namun, kemudian memeriksa dan memperbaiki yang mana yang salah. Koreksio: Ungkapan dengan menyebutkan hal-hal yang dianggap keliru atau kurang tepat, kemudian disebutkan maksud yang sesungguhnya. Dipakai untuk membetulkan kembali apa yang salah diucapkan baik yang disengaja maupun tidak.

Contoh:

Dia adikku! Eh, bukan, dia kakakku!

13) Antropomorfisme 
Metafora yang menggunakan kata atau bentuk lain yang berhubungan dengan manusia untuk hal yang bukan manusia. Majas Antropomorfisme adalah majas Metafora yang menggunakan kata atau bentuk lain yang berhubungan dengan manusia untuk hal yang bukan manusia.

Contoh:

Mulut gua itu sangat sempit.

14) Sinestesia

Majas yang berupa suatu ungkapan rasa dari suatu indra yang dicurahkan lewat ungkapan rasa indra lainnya. Dalam majas sinestesis, perbandingan dilakukan dengan cara membandingkannya dengan sesuatu yang dapat dirasakan oleh panca indera.

Contoh:

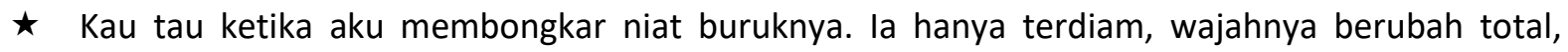
memucat masam.

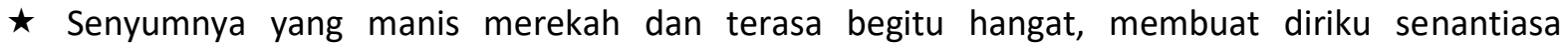
mengingatnya. Sulit sekali bagi diriku jika tak memikirkannya.

15) Antonomasia

Majas antonomasia merupakan penggunaan sifat sebagai nama diri atau nama diri lain sebagai nama jenis. Majas perbandingan yang menyebutkan sesuatu bukan dengan nama asli dari benda tersebut, melainkan dari salah satu sifat benda tersebut.

Contoh:

Hei Jangkung!

Si Pintar

Si Gemuk

Si Kurus

16) Aptronim

Majas Aptronim merupakan majas yang digunakan dalam pemberian nama yang cocok dengan sifat atau pekerjaan orang.

Contoh :

Sulit kalau bicara dengan Si Bolot, orang bertanya ke mana dijawab ke mana.

17) Metonimia

Pengungkapan berupa penggunaan nama untuk benda lain yang menjadi merek, ciri khas, atau atribut. Apabila sepatah kata atau sebuah nama yang berasosiasi dengan suatu benda dipakai untuk 
menggantikan benda yang dimaksud. Metonemia adalah bahasa kiasan dalam bentuk penggantian nama atas sesuatu.

Contoh:

$\star \quad$ Kita harus bersyukur tinggal di negeri Zamrud Khatulistiwa yang elok permai ini.

$\star$ Panda banyak terdapat di negeri Tirai Bambu.

$\star$ Ayah selalu mengisap Djarum Super (Djarum Super adalah merk rokok). Mengisap

Djarum Super artinya mengisap rokok merk Djarum Super.

18) Asosiasi

Majas asosiasi merupakan majas perbandingan yang cara melukiskan suatu hal dengan cara membandingkan suatu hal dengan hal lain, sesuai dengan keadaan hal yang dimaksud (Suprapto, 1991 : 14). Asosiasi adalah perbandingan terhadap dua hal yang berbeda, namun dinyatakan sama. Gaya bahasa ini memberikan perbandingan terhadap sesuatu benda yang sudah disebutkan. Perbandingan itu menimbulkan asosiasi terhadap banda sehingga gambaran tentang benda atau hal yang disebutkan itu menjadi lebih jelas.

Contoh:

Semangatnya keras bagai baja.

Pikirannya kusut bagai benang dilanda ayam.

Suaranya merdu bagai buluh perindu.

19) Hipokorisme

Penggunaan nama timangan atau kata yang dipakai untuk menunjukkan hubungan karib. Hipokorisme adalah penggunaan nama timangan atau kata yang dipakai untuk menunjukkan hubungan karib. Majas Hipokorisme adalah Penggunaan nama timangan atau kata yang dipakai untuk menunjukkan hubungan karib.

Contoh:

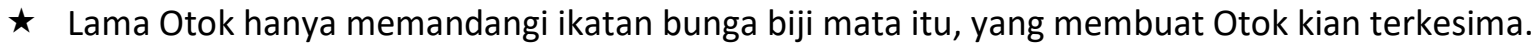

$\star$ Si Ujang sangat suka memancing.

20) Tropen

Majas tropen yaitu majas perbandingan yang cara menggambarkan suatui pekerjaan dengan menggunakan kata-kata yang memiliki pengertian yang sama (Suprapto, 1991 : 88). Majas tropen ialah kiasan yang memakai kata-kata yang tepat dan sejajar dengan arti yang dimaksud.

Contoh :

$\star \quad$ Tiap malam ia menjual suara dari satu panggung ke panggung lainnya. 
$\star$ Untuk membela anak istri, kurelakan walau bermandi darah.

$\star$ Pikirannya melayang-layang entah kemana.

\section{c. Majas Pertentangan}

Majas pertentangan yaitu majas yang cara melukiskan hal apapun dengan mempertentangkan antara hal yang satu dengan hal yang lainnya. Yang termasuk ke dalam jenis majas ini antara lain hiperbola, litotes, oksimoron, paronomasia, ironi, paralipsis, dan lain-lain.

1) Hiperbola

Hiperbola ialah gaya bahasa yang mengandung pernyataan yang berlebih-lebihan baik jumlah, ukuran, ataupun sifatnya dengan tujuan untuk menekan, memperhebat, meningkatkan kesan dan pengaruhnya. Hiperbola merupakan pengungkapan yang melebih-lebihkan kenyataan sehingga kenyataan tersebut menjadi tidak masuk akal. Adalah sepatah kata yang diganti dengan kata lain yang memberikan pengertian lebih hebat daripada kata lain.

Contoh:

$\star$ Harga-harga sudah meroket.

$\star$ Ketika mendengar berita itu, mereka terkejut setengah mati

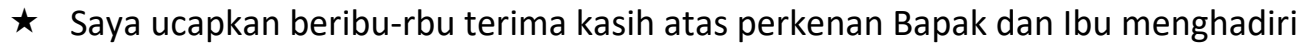
undangan panitia.

\section{2) Antitesis}

Pengungkapan dengan menggunakan kata-kata yang berlawanan arti satu dengan yang lainnya. Majas pertentangan yang menggunakan paduan kata yang berlawanan arti.

Contoh:

Tua muda, besar kecil, semuanya hadir di tempat itu.

\section{3) Anakronisme}

Ungkapan yang mengandung ketidaksesuaian dengan antara peristiwa dengan waktunya. Anakronisme merupakan majas yang mengungkapkan sesuatu yang bertentangan dengan waktu kejadian yang dibicarakan (anakronisme, ana $=$ mundur; chronos $=$ waktu). Biasanya majas ini digunakan untuk menceritakan sesuatu yang telah terjadi (masa lalu atau sejarah) dan menambahkan unsur-unsur yang belum ada kala itu dalam menyatakan sesuatu.

\section{Contoh :}

Sambil menyalakan TV, sekali-sekali Hang Tuah melirik jam tangan Titusnya. Sementara tidak jauh, tampak Hang Jebat sedang bermain golf.. 


\section{4) Litotes}

Litotes ialah majas yang berupa pernyataan yang bersifat mengecilkan kenyataan yang sebenarnya. Litotes : ungkapan berupa penurunan kualitas suatu fakta dengan tujuan merendahkan diri. Apabila kita menggunakan kata yang berlawanan artinya dengan yang dimaksud dengan merendahkan diri terhadap orang yang berbicara.

Contoh:

Sekali-kali datanglah ke gubuk reotku.

5) Ironi

Ironi ialah gaya bahasa yang berupa pernyataan yang isinya bertentangan dengan kenyataan yang sebenarnya. Ironi merupakan sindiran dengan menyembunyikan fakta yang sebenarnya dan mengatakan kebalikan dari fakta tersebut. lalah salah satu majas sindiran yang dikatakan sebaliknya dari apa yang sebenarnya dengan maksud menyindir orang dan diungkapkan secara halus. Ironi/ sindiran adalah gaya bahasa berupa penyampaian kata-kata denga berbeda dengan maksud dengan sesungguhnya, tapi pembaca/pendengar, di harapkan memahami maksud penyampaian itu.

Contoh:

Kuakui, kutu buku yang satu ini memang berpengetahuan luas sekali.

\section{6) Oksimoron}

Oksimoron ialah gaya bahasa yang berupa pernyataan yang di dalamnya mengandung pertentangan dengan menggunakan kata-kata yang berlawanan dalam frase atau dalam kalimat yang sama. Karakteristik yang membedakannya dengan majas paradoks ialah pada oksimoron pertentangan diucapakan dalam satu frase yang sama.

Contoh:

Olahraga mendaki gunung memang amat menarik walupun sangat membahayakan.

7) Paronomosia

Paronomasia ialah gaya bahasa yang berupa pernyataan yang berisi penjajaran kata-kata yang sama bunyinya, tetapi berlainan maknanya.

Contoh:

Bisa ular itu bisa masuk ke sel-sel darah.

\section{8) Zeugma}

Zeugma ialah gaya bahasa yang menggunakan dua konstruksi rapatan dengan cara menghubungkan sebuah kata dengan dua atau lebih kata lain. Dalam zeugma kata yang dipakai untuk membawahkan 
kedua kata berikutnya sebenarnya hanya cocok untuk salah satu dari padanya. Zeugma: Silepsi dengan menggunakan kata yang tidak logis dan tidak gramatis untuk konstruksi sintaksis yang kedua, sehingga menjadi kalimat yang rancu. Zeugma adalah majas yang merupakan koordinasi atau gabungan gramatis dua kata yang mengandung ciri-ciri semantik yang bertentangan, seperti abstrak dan kongkrit.

Contoh:

Kami mendengar berita itu dari radio dan membacanya di surat kabar.

\section{9) Silepsis}

Dalam silepsis kata yang dipergunakannya itu secara gramatikal benar, tetapi kata tadi diterapkan pada kata lain yang sebenarnya mempunyai makna lain. Silepsis: Penggunaan satu kata yang mempunyai lebih dari satu makna dan yang berfungsi dalam lebih dari satu konstruksi sintaksis.

Contoh:

Fungsi dan sikap bahasa.

Seharusnya: Fungsi bahasa dan sikap bahasa. Fungsi bahasa maknanya fungsi dari bahasa, sikap bahasa maknanya sikap terhadap bahasa (Diksi dan Gaya Bahasa, Gorys Keraf)

10) Satire

Satire ialah gaya bahasa sejenis argumen atau puisi atau karangan yang berisi kritik sosial baik secara terang-terangan maupun terselubung. Satire: Ungkapan yang menggunakan sarkasme, ironi, atau parodi, untuk mengecam atau menertawakan gagasan, kebiasaan, dll. Satire adalah gaya bahasa sejenis ironi yang mengandung kritik atas kelemahan manusia agar terjadi kebaikan. Tidak jarang satire muncul dalam bentuk puisi yang mengandung kegetiran tapi ada kesadaran untuk berbenah diri.

Contoh:

Aku lalai di pagi hari

Beta lengah di masa muda

Kini hidup meracun hati

Miskin ilmu miskin harta

(Bait II puisi Menyesal karya M. Ali Hasymi)

11) Antifrasis

Antifrasis ialah gaya bahasa yang berupa pernyataan yang menggunakan sebuah kata dengan makna kebalikannya. Berbeda dengan ironi, yang berupa rangkaian kata yang mengungkapkan sindiran dengan menyatakan kebalikan dari kenyataan, sedangkan pada antifrasis hanya sebuah kata saja yang menyatakan kebalikan itu.

Contoh Antifrasis: 
Lihatlah si raksasa telah tiba (maksudnya si cebol).

Contoh ironi:

Kami tahu bahwa kau memang orang yang jujur sehingga tak ada satu orang pun yang percaya padamu.

12) Paradoks

Paradoks ialah gaya bahasa yang mengandung pertentangan yang nyata dengan fakta-fakta yang ada. Paradoks: Pengungkapan dengan menyatakan dua hal yang seolah-olah bertentangan, namun sebenarnya keduanya benar. Majas ini terlihat seolah-olah ada pertentangan. Paradoks adalah gaya bahasa berupa pernyataan yang mengandung kontras atau pertentangan, namun ternyata mengandung kebenaran.

Contoh:

Betapa banyak orang yang dalam kesendiriannya merasa kesepian di kota sehiruk-pikuk Jakarta.

13) Klimaks

Klimaks ialah gaya bahasa yang berupa susunan ungkapan yang makin lama makin mengandung penekanan atau makin meningkat kepentingannya dari gagasan atau ungkapan sebelumnya. Klimaks: Pemaparan pikiran atau hal secara berturut-turut dari yang sederhana/ kurang penting meningkat kepada hal yang kompleks/lebih penting. Klimaks, yang disebut juga gradasi, adalah gaya bahsa berupa ekspresi dan pernyataan dalam rincian yang secara periodek makin lama makin meningkat, baik kuantitas, kualitas, intensitas, nilainya. Klimaks dalah semacam gaya bahasa yang menyatakan beberapa hal yang dituntut semakin lama semakin meningkat.

\section{Contoh :}

$\star$ Kesengsaraan akan membuahkan kesabaran, kesabaran membuahkan pengalaman, dan pengalaman membuahkan harapan.

$\star$ Dalam apresiasi sastra, mula-mula kita hanya membaca selayang pandang puisi yang akan kita apresiasi, lalu kita membaca berulang-ulang sampai paham maksudnya, merasakan keindahannya, terus mengkajidalami, bisa membawakannya penuh penghayatan, sampai kita mampu menghargai keberadaan dan mencintainnya, syukur juga terpangil untuk kreatif menciptakan bentuk-bentuk sastra.

\section{4) Anti klimaks}

Antiklimaks ialah suatu pernyataan yang berisi gagasan-gagasan yang disusun dengan urutan dari yang penting hingga yang kurang penting. Antiklimaks: Pemaparan pikiran atau hal secara berturut-turut dari yang kompleks/lebih penting menurun kepada hal yang sederhana/kurang penting. Antiklimaks merupakan antonim dari klimaks adalah gaya bahasa berupa kalimat terstruktur dan isinya mengalami penurunan kualitas, kuantitas intensitas. Gaya bahasa ini di mulai dari puncak makin lama makin ke 
bawah. Dengan demikian, antiklimaks adalah gaya bahasa yang menyatakan beberapa hal berurutan semakin Ima semakin menurun.

Contoh :

$\star \quad$ Ketua pengadilan negeri itu adalah orang yang kaya, pendiam, dan tidak terkenal namanya.

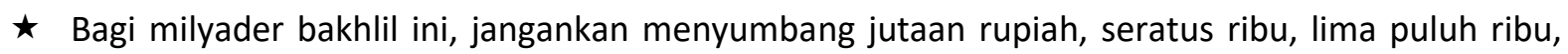
sepuluh ribu, seribu rupiah pun ia enggan, masih dihitung-hitung.

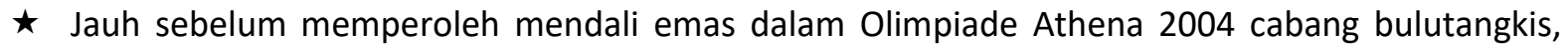
Taufik Hidayat niscaya telah menjadi juara nasional dan sebelumnya juga tingkat propinsi, kabupaten, malahan pula tingkat kecamatan, desa, RT/RW.

15) Apostrof

Apostrof ialah gaya bahasa yang berupa pengalihan amanat dari yang hadir kepada yang tidak hadir. Apostrof adalah gaya bahsa berupa pengalihan pembicaraan kepada benda atau sesuatu yang tidak bisa berbicara kepada kita terutama kepada tokoh yang tidak hadir atau sudah tiada, dengan tujuan lebih menarik atau memberi nuansa lain.

Contoh:

$\star \quad$ Wahai Dewa Yang Agung, datanglah dan lepaskan kami dari kuku cengkraman durjana.

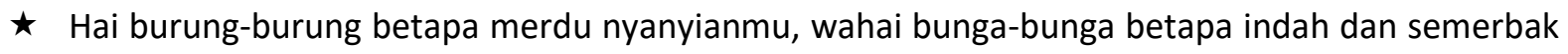
aromamu, wahai embun pagi, betapa jernih berkilau kamu laksana butiran-butiran intan tertimpa hangat sinar surya.

16) Anastrof atau inversi

Anastrof ialah gaya bahasa retoris yang diperoleh dengan membalikkan susunan kata dalam kalimat atau mengubah urutan unsur-unsur konstruksi sintaksis. Inversi artinya menyebutkan terlebih dahulu predikat dalam suatu kalimat sebelum subjeknya.

Contoh:

$\star$ Diceraikannya istrinya tanpa setahu saudara-saudaranya.

$\star$ Mobil ini baru sekali. $\rightarrow$ Baru sekali mobil ini.

$\star$ Buku ini menarik. $\rightarrow$ Menarik buku ini.

17) Apofasis atau Preterisio

Apofasis/preterisio adalah gaya bahasa yang dipakai oleh pengarang untuk menyampaikan sesuatu yang megandung unsur kontradiksi, kelihatannya menolak tapi sebenarnya menerima, kelihatannya memuji tapi sebenarnya mengejek, sekilas nampaknya membenarkan tapi sebenarnya menyalahkan, 
kelihatannya merahasiakan tapi sebenarnya membeberkan. Apofasismerupakan penegasan dengan cara seolah-olah menyangkal yang ditegaskan

Contoh :

^ Sebenarnya saya tidak sampai hati mengatakan bahwa anakmu kurang ajar.

$\star$ Saya tidak mau berterus terang kepada wartawan bahwa anda telah menggelapkan uang negara.

18) Histeron Proteran

Histeron Proteran ialah merupakan bahasa pertentangan yang sengaja digunakan pengarang yang isinya merupakan kebalikan dari suatu yang logis atau kebalikan dari sesuatu yang wajar.

Contoh :

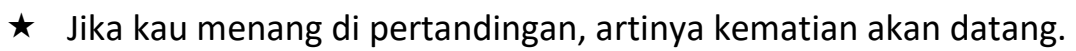

$\star \quad J i k a$ kau lulus ujian, kau akan ku usir dari sini.

19) Hipalase

Hipalase ialah gaya bahasa yang berupa sebuah pernyataan yang menggunakan kata untuk menerangkan suatu kata yang seharusnya lebih tepat dikarenakan kata yang lain. Hipalase adalah majas yang berupa pernyataan sindiran yang bermakna lain dari yang dimaksudkan.

\section{Contoh:}

la duduk pada bangku yang gelisah.

20) Sinisme

Sinisme ialah gaya bahasa yang merupakan sindiran yang berbentuk kesangsian yang mengandung ejekan terhadap keikhlasan atau ketulusan hati. Sinisme: Ungkapan yang bersifat mencemooh pikiran atau ide bahwa kebaikan terdapat pada manusia (lebih kasar dari ironi).

Contoh:

$\star \quad$ Kau memang hebat hingga pasir di gurun sahara pun dapat kau hitung.

$\star$ Muntah aku melihat perangaimu yang tak pernah berubah!

$\star$ Jijik aku mendengar kebiasaannya yang tak pernah berubah.

21) Sarkasme

Sarkasme ialah gaya bahasa yang mengandung sindiran atau olok-olok yang pedas atau kasar. Sarkasme: Sindiran langsung dan kasar. Gaya bahasa sindiran yang terkasar dimana memaki orang dengan katakata kasar dan tak sopan.

Contoh: 
Soal semudah ini saja tidak bisa dikerjakan. Goblok kau!

22) Innuendo

Sindiran yang bersifat mengecilkan fakta sesungguhnya. Inuendo adalah majas sindiran dengan cara mengecilkan kenyataan yang sebenarnya.

Contoh :

la memang cantik, hanya saja suka berbohong.

23) Kontradiksi interminus

Pernyataan yang bersifat menyangkal yang telah disebutkan pada bagian sebelumnya. Yaitu majas yang memperlihatkan sesuatu yang bertentangan dengan apa yang sudahdikatakan semula. Apa yang sudah dikatakan, disangkal lagi oleh ucapan kemudian.

Contoh:

Semuanya sudah hadir, kecuali Si Amir.

24) Praterito

Majas praterito yaitu majas yang cara mengungkapkan suatu hal dengan cara menyembunyikan maksud. Pendengar atau pembaca harus mencari atau menebak apa yang tersembunyi tersebut namun pendengar atau pembaca sudah paham dan mengerti terhadap hal yang disembunyikan itu. (Suprapto, $1991: 64)$.

Contoh :

Kejadian kemarin betul-beul mempermalukan warga sekampung.

25) Alonim

Majas alonim digunakan dalam penggunaan varian dari nama untuk menegaskan. Majas alonim merupakan majas yang menggunakan varian nama untuk menjelaskan sesuatu.

Contoh:

Dok, pasien sudah selesai ditrepanasi. (Dok adalah varian dari dokter).

26) Kolokasi

Majas kolokasi digunakan untuk asosiasi tetap antara suatu kata dengan kata lain yang berdampingan dalam kalimat. Majas ini mengasosiasikan satu kata dengan kata yang lain.

Contoh: 
Mobil itu berderit ketika sopir menginjak rem tiba-tiba di tikungan, meninggalkan bekas ban yang tajam di jalanan yang berdebu.

27) Okupasi

Majas okupasi merupakan majas pertentangan atau berlawanan yang mengandung bantahan namun bantahan tersebut kemudian diberi penjelasan (Suprapto, $1991: 56$ ).

Contoh :

Candu dapat merusak kehidupan, oleh karena itu pemerintah mengawasi dengan ketat, untuk pecandunya sendiri, umumnya tidak dapat menghentikan kebiasaan yang tidak baik tersebut.

\section{d. Majas Pertautan}

Majas pertautan yang cara menjelaskan suatu keadaan dengan mengaitkan hal yang dimaksud dengan lainnya yang memiliki sifat yang berkarakteristik sama atau mirip. Yang termasuk ke dalam jenis majas pertautan di antaranya metonimia, sinekdot, alusio, eufimisme, elipsis, inverse, dan lain-lain.

\section{1) Metonimia}

Metonimia berasal dari bajasa Yunani 'meta' yang artinya pertukaran dan 'onym' yang artinya nama. Metonimia merupakan sejenis majas yang menggunakan nama suatu benda untuk suatu hal lain yang memiliki keterkaitan dengan benda yang dimaksud. Dalam metonimia, suatu benda disebutakan tetapi yang dimaksud adalah benda lain (Dale (et all), 1971 : 234). Majas metonimia merupakan majas yang mempergunakan nama ciri ataui ciri hal yang menjadi cirri terhadap hal yang dimaksud kemudian ditautakan denngan mausia, barang, atau apapun sebagai gantinya (Suprapto, 1991 : 50). Metonimia ialah gaya bahasa yang menggunakan nama barang, orang, hal, atau ciri sebagai pengganti barang itu sendiri.

Metonimia adalah majas yang memakai nama ciri atau nama hal yang ditautkan dengan orang, barang atau hal, sebagai penggantinya. Kita dapan menyebut penciptanya atau pembuatnya, jika yang kita maksudkan ciptaan atau buatannya, ataupun kita dapat menyebut bahannya jika yang kita maksudkan barangnya (Moeliono,1984:3)

Contoh:

Ayah baru saja membeli Suzuki dengan harga lima juta rupiah.

2) Antanaklasis

Menggunakan perulangan kata yang sama, tetapi dengan makna yang berlainan. Antanaklasis merupakan bentuk majas perulangan yang memiliki pengulangan kata yang sama tetapi berbeda maksudnya. Jadi, majas antanaklasis itu majas yang menulang kata homonimi (Ducrot dan Todorov, 1981 : 227). 
Contoh :

Angga membawa kembang untuk kembang desa yang dipujanya.

3) Simbolik

Simbolik adalah majas yang menggambarkan sesuatu yang menggunakan benda-benda sebagai simbol atau lambang. Majas simbolik melukiskan sesuatu dengan menggunakan simbol atau lambang untuk menyatakan maksud.

Contoh :

Cintaku kepadamu tak akan pernah layu, bagai bunga surga.

4) Sinekdoke

Sinekdoke ialah gaya bahasa yang menyebutkan nama sebagian sebagai nama pengganti barang sendiri. Sinekdoke adalah bahasa kiasan dengan cara menyebutkan sesuatu bisa sebagian untuk menyatakan keseluruhan (pars pro toto), bisa pula sebaliknya keseluruhan digunakan untuk menyebut yang sebagian (totem pro parte). Pars pro toto: Pengungkapan sebagian dari objek untuk menunjukkan keseluruhan objek. Totem pro parte: Pengungkapan keseluruhan objek padahal yang dimaksud hanya sebagian.

Contoh Sinekdoke pars pro toto:

Lima ekor kambing telah dipotong pada acara itu.

Contoh Sinekdoke totem pro parte:

Dalam pertandingan itu Indonesia menang satu lawan Malaysia.

5) Alusio

Alusio ialah gaya bahasa yang menunjuk secara tidak langsung ke suatu pristiwa atau tokoh yang telah umum dikenal/ diketahui orang. Alusio adalah majas yang menggunakan pribahasa atau ungkapan. Alusi adalah majas yang secara tidak langsung menunjuk kepada tokoh, tempat, atau peristiwa.

Contoh:

Apakah peristiwa Madiun akan terjadi lagi di sini?

6) Eufimisme

Eufimisme ialah ungkapan yang lebih halus sebagai pengganti ungkapan yang dirasa lebih kasar yang dianggap merugikan atau yang tidak menyenangkan. Eufimisme: Pengungkapan kata-kata yang dipandang tabu atau dirasa kasar dengan kata-kata lain yang lebih pantas atau dianggap halus. Eufemisme adalah gaya bahasa berupa pengungkapan yang sifatnya menghaluskan supaya tidak menyinggung perasaan, tidak terasa tajam. Eufimisme berasal dari bahasa Yunani 'euphemizein' yang berarti 'berbicara dengan menggunakan kata-kata yang jelas dan wajar'. Euphemizein diturunkan dari 
kata 'eu' yang berarti baik atau bagus 'phanai' yang berarti bicara. Jadi jelas, eufimisme artinya pandai berbicara baik (Dale (et all) $1971: 239$ ).

Contoh:

Karena melakukan suatu perbuatan yang kurang pas, Pak Bandot akhirnya dikenai pensiun dini. (Terlibat skandal, korupsi, dipecat, di PHK).

7) Disfemisme

Majas disfemisme adalah pengungkapan pernyataan tabu atau yang dirasa kurang pantas sebagaimana adanya.

Contoh :

Hati-hati, kita mulai masuk hutan larangan. Di sini banyak hantu!

8) Eponim

Eponim ialah gaya bahasa yang menyebut nama seseorang yang begitu sering dihubungkan dengan sifat tertentu sehingga nama itu dipakai untuk menyatakan sifat itu. Eponim: Menjadikan nama orang sebagai tempat atau pranata. Eponim adalah majas dimana nama dari seseorang begitu sering dihubungakan dengan sifat tertentu, sehingga nama tersebut dipakai sebagai pengganti dari sifat orang tersebut.

Contoh:

Dengan latihan yang sungguh-sungguh, saya yakin Anda akan menjadi Mike Tyson.

9) Antonomasia

Antonomasia ialah gaya bahasa yang berupa pernyataan yang menggunakan gelar resmi atau jabatan sebagai pengganti nama diri. Penggunaan sifat sebagai nama diri atau nama diri lain sebagai nama jenis. Antomasia dalah majas yang memakai sifat atau ciri tubuh, gelar atau jabatan seseorang sebagai pengganti nama diri.

Contoh:

Kepala sekolah mengundang para orang tua murid.

10) Epitet

Epitet ialah gaya bahasa yang berupa keterangan yang menyatakan sesuatu sifat atau ciri yang khas dari seseorang atau suatu hal.

Contoh:

Dewi malam menyambut kedatangan sepasang remaja yang sedang dimabuk asmara. 


\section{1) Erotesis}

Majas erotesis merupakan majas yang mengungkapkan sesuatu dalam bentuk pertanyan yang tidak menuntut atau memerlukan suatu jawaban. Erotesis ialah gaya bahasa yang berupa pertanyaan yang tidak menuntut jawaban sama sekali. Erotesis atau pertanyaan retoris

ialah pernyataan yang dipergunakan dalam pidato atau tulisan dengan tujuan untuk mencapai efek yang lebih mendalam dan penekanan yang wajar, dan sama sekali tidak menghendaki adanya suatu jawaban.

Contoh:

Tegakah membiarkan anak-anak dalam kesengsaraan?

Apakah kau akan terus membiarkan cintamu menjauh?

Dimana letak akal para penipu rakyat itu?

12) Paralelisme

Paralelisme ialah gaya bahasa yang berusaha menyejajarkan pemakaian kata-kata atau frase-frase yang menduduki fungsi yang sama dan memiliki bentuk gramatikal yang sama. Paralelisme: Pengungkapan dengan menggunakan kata, frase, atau klausa yang sejajar. Pengulangan kata-kata untuk menegaskan yang terdapat pada puisi. Bila kata yang diulang pada awal kalimat dinamakan anaphora, dan jika terdapat pada akhir kalimat dinamakan evipora.

Contoh:

Kau berkertas putih

Kau bertinta hitam

Kau beratus halaman

Kau bersampul rapi.

Kalau kau mau aku akan datang

Jika kau menginginkan aku akan datang

Bila kau minta aku akan datang

Andai kau ingin aku akan datang

+ Bukan saja perbuatan itu harus dikutuk, tetapi juga harus diberantas.

- Bukan saja perbuatan itu harus dikutuk, tetapi juga harus memberantasnya (Ini contoh yang tidak baik).

13) Elipsis 
Elipsis ialah gaya bahasa yang di dalamnya terdapat penanggalan atau penghilangan salah satu atau beberapa unsur penting dari suatu konstruksi sintaksis. Elipsis: Penghilangan satu atau beberapa unsur kalimat, yang dalam susunan normal unsur tersebut seharusnya ada. Elipsis adaklah gaya bahasa berupa penyusunan kalimat yang mengandung kata-kata yang sengaja dihilangkan yang sebenarnya bisa diisi oleh pembaca/penyimak.

Contoh:

$\star$ Pembangunan mencakup dua hal yakni pembangunan material dan ......., pembangunan lahiriah dan ........., pembangunan individual dan

* Apa saja yang ada di dunia serta berpasangan ada siang ada ada baik ada ada terang ada ...... , ada pertemuan ada , roda berputar kadang di atas kadang

14) Gradasi

Gradasi ialah gaya bahasa yang mengandung beberapa kata (sedikitnya tiga kata) yang diulang dalam konstruksi itu. Gradasi yaitu majas yang memiliki rangkaian atau urutan sedikitnya tiga kata atau istilah yang secara sintaksis kata atau istilah tersebut memiliki satu ciri semantik atau lebih (Ducrot dan Todorov, $1981: 277$ ).

Contoh :

Kita tengah berjuang melawan musuh dengan satu tekad, tekad terus maju, maju dalam kehidupan, kehidupan yang baik, baik secara rohani ataui jasmani, rohani atau jasmani yang diridhoi, diridhoi oleh Gusti Allah, Gusti Allah yang memiliki hidup dan mati. Hidup dan mati kita semua.

15) Asindeton

Asindenton ialah gaya bahasa yang berupa sebuah kalimat atau suatu konstruksi yang mengandung kata-kata yang sejajar, tetapi tidak dihubungkan dengan kata-kata penghubung. Asindeton: Pengungkapan suatu kalimat atau wacana tanpa kata penghubung. Beberapa hal keadaan atau benda disebutkan berturut-turut tanpa menggunakan kata penghubung.

Contoh:

Meja, kursi, lemari ditangkubkan dalam kamar itu.

Ayah, ibu, anak merupakan inti dari sebuah keluarga.

16) Polisindeton

Polisindenton ialah gaya bahasa yang berupa sebuah kalimat atau sebuah konstruksi yang mengandung kata-kata yang sejajar dan dihubungkan dengan kata-kata penghubung. Polisindenton: Pengungkapan suatu kalimat atau wacana, dihubungkan dengan kata penghubung.

Contoh: 
Pembangunan memerlukan sarana dan prasarana juga dana serta kemampuan pelaksana.

17) Retoris

Ungkapan pertanyaan yang jawabannya telah terkandung di dalam pertanyaan tersebut. Gaya bahasa penegasan ini mempergunakan kalimat Tanya-tak-bertanya. Sering menyatakan kesangsian atau bersifat mengejek. Erotesis/pertanyaan retoris adalah gaya bahasa berupa pengajuan pertanyaan untuk memperoleh efek mengulang tanpa menghendaki jawaban, karena jawabannya sudah tersirat di sana. Gaya bahasa ini acap digunakan oleh para orator.

Contoh:

Biaya pendidikan di Perguruan Tinggi sangat mahal. Bisakah rakyat kecil menyekolahkan anaknya sampai ke sana?

18) Interupsi

Ungkapan berupa penyisipan keterangan tambahan di antara unsur-unsur kalimat. Gaya bahasa penegasan yang mempergunakan sisipan di tengah-tengah kalimat pokok, denagn maksud untuk menjelaskan sesuatu dalam kalimat tersebut. Gaya bahasa yang memakai kata-kata atau bagian kalimat yang disisipkan di dalam kalimat pokok untuk lebih menjelaskan sesuatu dalam kalimat.

Contoh:

Tiba-tiba la - kekasih itu - direbut oleh perempuan lain.

19) Enumerasio

Majas enumerasio yaitu majas gaya bahasa penegasan yang melukiskan atau menggambarkan suatu kejadian atau peristiwa agar seluruh maksud di dalam kalimat tersebut menjadi lebih lugas dan jelas (Suprapto, $1991: 27$ ).

Contoh :

Angin semilir perlahan, langit biru terlihat ringan, lazuardi cerah nilakandi, bulan pun bersinar kembali, sedang aku, cuma duduk sambil melamun.

20) Resentia

Adalah gaya bahasa yang melukiskan sesuatu yang tidak mengatakan tegas pada bagian tertentu dari kalimat yang dihilangkan. Resentia adalah gaya bahasa yang menggambarkan sesuatu yang tidak bermaksud tegas pada bagian tertentu dari kalimat.

Contoh :

Apakah ibu mau....?

Apakah kamu suka...? 


\section{1) Anakuloton}

Majas anakuloton merupakan majas yang dalam pemakaian kalimatnya sengaja disimpangkan dari kaidah-kaidah penulisan tata basa (Suprapto, 1991 : 11).

Contoh :

Jangan berebut, coba barisnya yang tartib!

22) Meiosis

Majas meiosis merupakan penegasan yang cara mengungkapkan suatu hal atau keadaan dengan menggunakan pernyataan yang halus. Majas ini sering digunakan secara ironi, khususnya untuk menggambarkan suatu hal yang luar biasa (Suprapto, $1991: 49$ ).

Contoh :

Hasil panennya agak kurang baik (untuk menyatakan panen gagal).

23) Simetrisme

Majas simetriisme merupakan majas yang menyatakan suatu kalimat dengan menggunakan kata-kata yang lain ananum sesungguhnya kalimat tersebut mengandung makna yang sama (Suprapto, 1991 : 82).

Contoh :

$\star$ Anak tersebut sudah dididik, diajar, dituntun berjalan direl yang benar.

$\star$ Ayahku sudah pergi dan tak mungkin kembali lagi.

\section{DAFTAR PUSTAKA}

Abrams, M.H. 1976. The Mirror and The Lamp : Romantic Theory and The Critical Tradition. New York: Holt, Rinehart and Winston.

Aminuddin. 1995. Stilistika: Pengantar Memahami Bahasa dalam Karya Sastra. Semarang: IKIP Semarang Press.

Bradford, Richard. 1997. Stylistics. London: New Fetter Lane.

Bressler, Charles E. 1999. Literary Criticism : An Introduction to Theory and Practice. Second Edition. New Jersey: Prentice Hall, Upper Saddle River.

Child, Peter and Roger Fowler. 2006. The Routledge Dictionary of Literary Terms. London and New York: Routledge.

Darmono, S. D. 2003. Kita dan Sastra Dunia. dalam http://www.mizan.com. diakses pada tanggal 13 Januari 2012. 
Darwis, Muhammad. 2002. Pola-Pola Gramatikal dalam Puisi Indonesia. Dalam Jurnal Masyarakat Linguistik Indonesia edisi Tahun 20, Nomor 1, Februari 2002.

Davies, Alan and Catherine Elder (Ed). 2006. The Handbook of Applied Linguistics. Australia: Blackwell Publishing.

Depdiknas. 2005. Kamus Besar Bahasa Indonesia (edisi 3). Jakarta: Balai Pustaka.

Endaswara, Suwardi. 2003. Metodologi Penelitian Sastra. Yogyakarta: Pustaka Widyatama.

Fabb, Nigel. 2003. Linguistics and Literature. In Mark Arnoff and Janie Rees-Miller (Ed), The Handbook of Linguistics. USA: Blackwell Publisher.

Junus, Umar. 1989. Stilistika : Satu Pengantar. Kuala Lumpur: Dewan Bahasa dan Pustaka.

Keraf, Gorys. 2006. Diksi dan Gaya Bahasa (cetakan XVI). Jakarta: PT Gramedia Pustaka Utama.

Keraf, Gorys. 2009. Diksi dan Gaya bahasa. Jakarta: Gramedia Pustaka Utama.

Kridalaksana, Harimurti. 2001. Kamus Linguistik (edisi IV). Jakarta: PT Gramedia Pustaka Utama.

Mikics, David. 2007. A New Handbook of Literary Term. London: Yale University Press.

Mills, Sara. 1995. Feminist Stylistics. London and New York: Routledge.

Missikova, Gabriela. 2003. Linguistics Stylistics. Nitra: Filozoficka Fakulta Univerzita Konstantina Filozofa.

Musthafa, Bachrudin. 2008. Teori dan Praktik Sastra dalam Penelitian dan Pengajaran. Bandung: UPI.

Nurgiyantoro, Burhan. 1995. Teori Pengkajian Fiksi. Yogyakarta: Gadjah Mada University Press.

Nurgiyantoro, Burhan. 2005. Teori Pengkajian Fiksi. Yogyakarta: Gajah Mada University Press.

Pradopo, Rachmat Djoko. 1997. Pengkajian Puisi Analisis Strata Norma dan Analisis Struktural dan

Semiotik. Yogyakarta: Gadjah Mada University Press.

Pranawa, Erry. 2005. Analisis Stilistika Novel Burung-burung Manyar Karya Y.B. Mangunwijaya (Tesis). Program Studi Linguistik Pascasarjana Universitas Sebelas Maret Surakarta.

Ratna, Nyoman Kutha. 2009. Stilistika Kajian Puitika Bahasa Sastra dan Budaya. Yogyakarta: Pustaka Pelajar.

Renne Wellek \& Austin Warren, 1995. Penerjemah Melani Budianta, Teori Kesusastraan, Jakarta : PT Gramedia Pustaka Utama.

Sangidu. 2004. Penelitian Sastra Pendekatan Teori, Metode, Teknik dan Kiat. Yogyakarta: Unit Penerbitan Asia Barat.

Satoto, Soediro. 1995. Stilistika. Surakarta: STSI Press. 
Sayuti, Suminto A. 2001. Penelitian Stilistika : Beberapa Konsep Pengantar. Dalam Jabrohim (Ed) Metodologi Penelitian Sastra. Yogyakarta: Hanindita.

Shipley, Joseph T. 1979. Dictionary of World Literature : Forms, Technique, Critics.. USA: Boston The Writer, Inc.

Simpson, Paul. 2004. Stylistics : A Resource Book for Student. New York: Roudledge.

Starcke, Bettina Fischer. 2010. Corpus Linguistics in Literary Analysis. New York: Continuum nternationa Publishing Group.

Sudjiman, Panuti. 1993. Bunga Rampai Stilistik. Jakarta: Pustaka Utama Grafiti.

Suprapto. 1991. Kumpulan Istilah Sastra dan Apresiasi Sastra. Jakarta: Dian.

Tuloli, Nani. 2000. Kajian Sastra. Gorontalo: Nurul Jannah.

Lafamane, F. (2020). Tata Bahasa Fungsional (functional Grammar).

Lafamane, F. (2020). Fenomena Penggunaan Bahasa Daerah di Kalangan Remaja.

Amanto, B. S., Umanailo, M. C. B., Wulandari, R. S., Taufik, T., \& Susiati, S. (2019). Local Consumption Diversification. Int. J. Sci. Technol. Res, 8(8), 1865-1869.

Amri, M., Tahir, S. Z. A. B., \& Ahmad, S. (2017). The Implementation of Islamic Teaching in Multiculturalism Society: A Case Study at Pesantren Schools in Indonesia. Asian Social Science, 13(6), 125.

Andini, K. NILAI BUDAYA SUKU BAJO SAMPELA DALAM FILM THE MIRROR NEVER LIES KARYA KAMILA ANDINI.

ARYANA, A. PERBANDINGAN GAYA BAHASA DALAM NOVEL ATHEIS KARYA ACHDIAT KARTA MIHARDJA DAN NOVEL TELEGRAM KARYA PUTU WIJAYA: TINJAUAN STILISTIKA.

Azwan, A. (2018). Politeness strategies of refusals to requests by Ambonese community. LINGUA: Jurnal Bahasa, Sastra, Dan Pengajarannya, 15(1), 1-6.

Bin-Tahir, S. Z., Atmowardoyo, H., Dollah, S., Rinantanti, Y., \& Suriaman, A. (2018). MULTILINGUAL AND MONO-MULTILINGUAL STUDENTS'PERFORMANCE IN ENGLISH SPEAKING. Journal of Advanced English Studies, 1(2), 32-38.

Bin Tahir, S. Z. (2017). Multilingual teaching and learning at Pesantren Schools in Indonesia. Asian EFL Journal, 89, 74-94.

Bin Tahir, S. Z. (2015). The attitude of Santri and Ustadz toward multilingual education at Pesantren. International Journal of Language and Linguistics, 3(4), 210-216. 
Bin-Tahir, S. Z., \& Rinantanti, Y. (2016). Multilingual lecturers' competence in english teaching at the university of Iqra Buru, Indonesia. Asian EFL Journal, 5, 79-92.

Bin-Tahir, S. Z., Saidah, U., Mufidah, N., \& Bugis, R. (2018). The impact of translanguaging approach on teaching Arabic reading in a multilingual classroom. ljaz Arabi Journal of Arabic Learning, 1(1).

Bin-Tahir, S. Z., Bugis, R., \& Tasiana, R. (2017). Intercultural Communication of a Multicultural Family in Buru Regency. Lingual: Journal of Language and Culture, 9(2), 8.

Crystal, David. 2000. New Perspectives of Language Study 1 : Stylistics. University of Reading: Department of Linguistics Science.

Djamudi, N. L., Nurlaela, M., Nazar, A., Nuryadin, C., Musywirah, I., \& Sari, H. (2019, October). Alternative social environment policy through educational values in Kafi'a's customary speech to the kaledupa community of Wakatobi Island, Indonesia. In IOP Conference Series: Earth and Environmental Science (Vol. 343, No. 1, p. 012118). IOP Publishing..

Indonesia, K. K. D. B. Morfologi Bahasa Indonesia.

Iye, R., \& Susiati, S. (2018). NILAI EDUKATIF DALAM NOVEL SEBAIT CINTA DI BAWAH LANGIT KAIRO KARYA MAHMUD JAUHARI ALI (Educative Values in Sebait Cinta di Bawah Langit Kairo by Mahmud Jauhari Ali). Sirok Bastra, 6(2), 185-191.

Iye, R. (2018). Tuturan emosi mahasiswa kota baubau dalam ranah demonstrasi.

Iye, R., Susiati, S., \& Karim, K. (2020). Citra Perempuan dalam Iklan Sabun Shinzui. Sang Pencerah: Jurnal Ilmiah Universitas Muhammadiyah Buton, 6(1), 1-7.

lye, R. Jl Prof Dr HAR Basalamah No, and Namlea-Kab Buru.". TUTURAN DALAM PROSESI LAMARAN PERNIKAHAN DI TOMIA KABUPATEN WAKATOBI." Kontemporer. Bandung: PT Remaja.

Karim, K., Maknun, T., \& Abbas, A. (2019). Praanggapan Dalam Pamflet Sosialisasi Pelestarian Lingkungan Di Kabupaten Wakatobi. Jurnal IImu Budaya, 7(2), 241-247.

Lafamane, F. (2020). Tata Bahasa Sistemik Fungsional (Suatu Pandangan).

Lafamane, F. (2020). Perkembangan Teori Sastra (suatu Pengantar). OSF Preprints. July, 25.

Mansyur, F. A., \& Suherman, L. A. (2020). The Function of Proverbs as Educational Media: Anthropological Linguistics on Wolio Proverbs. ELS Journal on Interdisciplinary Studies in Humanities, 3(2), 271-286.

Rahayaan, I., Azwan, A., \& Bugis, R. (2016). The Students' Writing Ability through Cooperative Script Method. Jurnal Retemena, 2(2). 
Sadat, A., Nazar, A., Suherman, L. O. A., Alzarliani, W. O. D., \& Birawida, A. B. (2019, October). Environmental care behavior through e-jas model with science edutainment approach. In IOP Conference Series: Earth and Environmental Science (Vol. 343, No. 1, p. 012126). IOP Publishing.

Sadat, A., Sa'ban, L. M. A., Suherman, L. O. A., Bahari, S., Ibrahim, T., \& Zainal, M. (2019, October). Internalization characters of environmental care and disaster response through care partner schools. In IOP Conference Series: Earth and Environmental Science (Vol. 343, No. 1, p. 012125). IOP Publishing.

Salamun, T. (2018). DEIKSIS PERSONA BAHASA INDONESIA DIALEK AMBON [Personal Deixes of Indonesian Leanguage With Ambonese Dialect]. Totobuang, 5, 325-339.

Salamun, T. (2018). RELASI KEKERABATAN BAHASA HITU, WAKAL, MORELA, MAMALA, DAN HILA DI PROVINSI MALUKU [The Family Relationship Language Hitu, Wakal, Morela, Mamala, and Hila in Maluku Province].

Suherman, L. A. (2018). The Analysis of Metaphorical Domain on English "Stab Verb" in Corpora. ELS Journal on Interdisciplinary Studies in Humanities, 1(1), 52-58.

Suherman, L. O. A., Salam, S., Mursanto, D., Efendi, A., Bahar, S. B., \& Kanna, T. (2019, October). The effect of open-air curing on compressive strength of geopolymer mortar containing laterite soil and slaked lime. In IOP Conference Series: Earth and Environmental Science (Vol. 343, No. 1, p. 012133). IOP Publishing.

Susiati, S., \& Iye, R. (2018). Kajian Geografi Bahasa dan Dialek di Sulawesi Tenggara: Analisis Dialektometri. Gramatika: Jurnal IImiah Kebahasaan dan Kesastraan, 6(2), 137-151.

Susiati, S. Dialektometri Segitiga: Hubungan Kekerabatan Bahasa Di Sulawesi Tenggara (Bahasa Wakatobi, Bahasa Cia-Cia, Bahasa Pancana, Bahasa Kioko, Bahasa Tolaki).

Susiati, S., Iye, R., \& Suherman, L. O. A. (2019). Hot Potatoes Multimedia Applications in Evaluation of Indonesian Learning In SMP Students in Buru District. ELS Journal on Interdisciplinary Studies in Humanities, 2(4), 556-570.

Susiati, S. (2018). Homonim bahasa kepulauan tukang besi dialek kaledupa di kabupaten wakatobi [the homonymon of tukang besi island languange in kaledupa dialect at wakatobi regency]. Totobuang, 6 (1), 109, 123.

Susiati, S. (2020). Emosi Verbal Suku Bajo Sampela.

Susiati, S. (2020). Fenomena Tuturan Emosi Verbal Bahasa Indonesia Suku Bajo Sampela.

Susiati, S. (2020). Nilai Budaya Suku Bajo Sampela Dalam Film The Mirror Never Lies Karya Kamila Andini.

Susiati, S. (2020). Konsep Pertentangan Dalam Film" Aisyah Biarkan Kami Bersaudara" Karya Herwin Novianto. 
Susiati, S. (2020). Strategi AMBT untuk Meningkatkan Kemampuan Membaca Pemahaman Interpretatif Siswa Kelas IV SD Negeri 3 Namlea Kabupaten Buru.

Susiati, S. (2020). Fungsi Konatif Pada Iklan Mesin Cuci Hole-Less Tub Dari Sharp: Analisis Wacana Kritis.

Susiati, S. (2020). GAYA BAHASA SECARA UMUM DAN GAYA BAHASA PEMBUNGKUS PIKIRAN.

Susiati, S. (2020). The Concept Of Togetherness In The Films" Aisyah Biarkan Kami Bersaudara" By Herwin Novianto.

Susiati, S. (2020). Konsep Kebersamaan Dalam Film" Aisyah Biarkan Kami Bersaudara" Karya Herwin Novianto.

Susiati, S. (2020). Teori dan Aliran Linguistik: Tata Bahasa Generatif.

Susiati, S. (2020). Metode Pembelajaran Bahasa Indonesia: Sosiodrama.

Susiati, S. (2020). Rekontruksi Internal Bahasa Bugis dan Bahasa Makassar: Linguistik Komparatif.

Susiati, S. Bahan Ajar: Psikolinguistik.

Susiati, S. (2020). PENTINGNYA MELESTARIKAN BAHASA DAERAH.

Susiati, S. (2020). Morfologi Kelas Kata Dalam Bahasa Indonesia.

Susiati, S. (2020). Semantik: Teori Semantik, Relasi Makna, Marked, Dan Unmarked.

Susiati, Y. T. Risman Iye. A. Kesantunan Imperatif Bahasa Indonesia Suku Bajo Sampela: Balai Pembinaan dan Pengembangan Bahasa. 2018. Kongres Bahasa Indonesia (No. 12, pp. 1-6). Report.

Susiati, S. (2020). Internal Recontruction Bugis Language and Makassar Language.

Susiati, S. (2020). Kesantunan Imperatif Bahasa Melayu Ambon.

Susiati, S. (2020). Gaya Bahasa Secara Umum Dan Gaya Bahasa Pembungkus Pikiran: Stilistika.

Susiati, S. (2020). Tuturan Kesantunan Imperatif Bahasa Indonesia Suku Bajo Sampela.

Susiati, S. (2020). Nilai Budaya Suku Bajo Sampela Dalam Film The Mirror Never Lies Karya Kamila Andini.

Susiati, S. (2020). Pengaplikasian Multimedia Hot Potatoes Dalam Evaluasi Pembelajaran Bahasa Indonesia Pada Siswa SMP Negeri 9 Buru.

Susiati, S., \& lye, R. (2018). Kajian Geografi Bahasa dan Dialek di Sulawesi Tenggara: Analisis Dialektometri. Gramatika: Jurnal IImiah Kebahasaan dan Kesastraan. 6 (2), 137-151.

Susiati, S. (2020). Kaidah Fonologi Bahasa Indonesia.

Susiati, S. (2020). Wujud Morfologi Bahasa Indonesia. 
Susiati, S. (2020). Makian Bahasa Wakatobi Dialek Kaledupa.

Susiati, S. (2020). Eksistensi Manusia Dalam Film" Aisyah Biarkan Kami Bersaudara" Karya Herwin Novianto.

Susiati, S. NILAI BUDAYA SUKU BAJO SAMPELA DALAM FILM THE MIRROR NEVER LIES.

Susiati, S. (2020). Konsep Keterasingan Dalam Film" Aisyah Biarkan Kami Bersaudara" Karya Herwin Novianto.

Susiati, S. (2020). Concept Of Conflict In The Films "AISYAH BIARKAN KAMI BERSAUDARA" By Herwin Novianto.

Susiati, S. (2020). Embrio Nasionalisme Dalam Bahasa dan Sastra.

Susiati, S. PERWUJUDAN SIMILE OLEH MERARI SIREGAR DALAM NOVEL AZAB DAN SENGSARA.

Susiati, S. (2020). Nilai Pembentuk Karakter Masyarakat Wakatobi Melalui Kabhanti Wa Leja.

Tahir, S. Z. A. B. (2017). Pengembangan Materi Multibahasa untuk Siswa Pesantren. Unpublish dissertation.

Tahir, S. Z. B. (2015). Multilingual Teaching And Learning At Pesantren. 14 Asian EFL Journal Conference.

Tenriawali, A. Y. (2018). Representasi korban kekerasan dalam teks berita daring tribun timur: analisis wacana kritis [the representation victims of violence in tribun timur online news text: critical discourse analysis]. TOTOBUANG, 6 (1), 1, 15.

Yusdianti, A. (2020). THE REPRESENTATION VICTIMS OF VIOLENCE IN TRIBUN TIMUR ONLINE NEWS TEXT: CRITICAL DISCOURSE ANALYSIS.

Verdonk, Peter. 2002. Stylistics. New York: Oxford University Press.

Wellek, Rene dan Austin Warren. 1989. Teori Kesusastraan. Diterjemahkan oleh Melani Budianta. Jakarta: Gramedia.

Widdowson, H.G. 1997. Stilistika dan Pengajaran Sastra. Diterjemahkan oleh Sudijah. Surabaya: Airlangga University Press.

Wynne, Martin. 2005. Stylistics : Corpus Approaches. Oxford: Oxford University.

Yunus, Umar. 1989. Stilistika; Suatu Pengantar. Kuala Lumpur : Dewan Bahasa dan Pustaka.

Zhang, Zhiqin. 2010. The Interpretation of a Novel by Hemingway in Term of Literary.

Zulfahnur, dkk. 1996. Teori Sastra. Jakarta: Depdikbud 